\title{
Ultrasonographic and ecobiometric findings in the eyes of adult goats
}

\author{
Achados ultrasonográficos e ecobiométricos em olhos de cabras adultas
}

\begin{abstract}
Alexandre Pinto Ribeiro ${ }^{\mathrm{I}}$ Nailson Lima Santos ${ }^{\mathrm{II}}$ Victor Costa e Silva ${ }^{\mathrm{II}}$ Andressa Fernanda Campos ${ }^{\mathrm{II}}$ Izabelle Auxiliadora Molina de Almeida Teixeira ${ }^{\text {III }}$ José Luiz Laus ${ }^{\text {IV }}$
\end{abstract}

\begin{abstract}
The knowledge of the normal appearance and ocular dimensions of goat eyes facilitates the use of ultrasonography in the evaluation of ocular disease. The objective of the present study was to determine ultrasonographic and ecobiometric findings in the eyes of adult goats. B- and Amode ultrasonography was performed in 30 healthy adult goats (60 eyes) ( $n=5$ intact females and $n=15$ castrated males). Ultrasonography was performed after instillation of a topical anesthetic. Lubricating jelly was placed on the $20 \mathrm{MHz}$ transducer tip as a stand-off pad. The transducer was placed in a longitudinal position until optimal B-scan images, according to echoes of the A-mode images, were obtained. Statistical analysis was carried out to compare the ecobiometric readings among genders $(P<0.05)$. Means and standard deviations of the ocular structures for male and female goats, respectively, were, $3.46 \pm 0.55,3.33 \pm 0.46 \mathrm{~mm}$ (anterior chamber depth); $8.60 \pm 0.34,8.65 \pm 0.39 \mathrm{~mm}$ (lens thickness); $11.34 \pm 0.61$, $11.39 \pm 0.66 \mathrm{~mm}$ (vitreous chamber depth); and $23.43 \pm 0.92$, $23.39 \pm 0.86 \mathrm{~mm}$ (axial globe length). Ocular measurements between right and left eyes, as well as between males and females were not significantly different $(P>0.05)$. The ultrasonographic appearances of goat eyes were very similar to those of other domestic and wild species.
\end{abstract}

Key words: Capra hircus, ocular ultrasonography, ecobiometry

\section{RESUMO}

Conhecer o aspecto e as dimensões de olhos de cabras facilita o uso da ultrassonografia na avaliação de doenças oculares. O objetivo do presente trabalho foi o de avaliar os achados ultrassonográficos e ecobiométricos em olhos de cabras adultas. Ultrassonogramas nos modos $A$ e $B$ foram realizados em 30 caprinos adultos (60 olhos) ( $n=15$ fêmeas intactas e $n=15$ machos castrados). O exame ultrassonográfico foi realizado após a instilação de colírio anestésico. Gel a base de água foi utilizado sobre o transdutor de $20 \mathrm{MHz}$ posicionado-o de forma longitudinasobre a córneal, até que imagens no modo $B$ estivessem de acordo com os ecos gerados pelo modo A. Utilizou-se análise estatística para se comparar os achados ecobiométricos entre os sexos $(p<0,05)$. As médias com seus respectivos desvios padrões das estruturas oculares em machos e fêmeas foram, respectivamente, $3,46 \pm 0,55,3,33 \pm 0,46 \mathrm{~mm}$ (profundidade da câmara anterior); $8,60 \pm 0,34,8,65 \pm 0,39 \mathrm{~mm}$ (espessura da lente); $11,34 \pm 0,61$, $11,39 \pm 0,66 \mathrm{~mm}$ (profundidade da câmara vítrea) e 23,43 $\pm 0,92$, $23,39 \pm 0.86 \mathrm{~mm}$ (comprimento axial do bulbo ocular). Não foi observada diferença significativa entre os olhos direito $e$ esquerdo, assim como entre machos e fêmeas $(p>0,05)$. O aspecto ultrassonográfico de olhos de cabras se assemelha com o de outras espécies domésticas e silvestres.

Palavras-chave: Capra hircus, ultrassonografia ocular, ecobiometria

\section{INTRODUCTION}

It is known that ocular diseases in foodproducing animals play a significant role in economic losses (WHITTAKER et al., 2003; POTTER et al., 2008). In goats, outbreaks of infectious keratoconjunctivitis

'Programa de Pós-graduação em Cirurgia Veterinária, Faculdade de Ciências Agrárias e Veterinárias (FCAV), Universidade Estadual Paulista (UNESP), Jaboticabal, SP, Brasil.

"Programa de Pós-graduação em Zootecnia, FCAV/UNESP, Jaboticabal, SP, Brasil.

IIIDepartamento de Zootecnia, FCAV/UNESP, Jaboticabal, SP, Brasil.

${ }^{\mathrm{IV}}$ Departamento de Clínica e Cirurgia Veterinária, FCAV/UNESP, Via de acesso Professor Paulo Donato Castellane, 14870-000, Jaboticabal, SP, Brasil. E-mail: jllaus@fcav.unesp.br. Autor para correspondência. 
and cases of phenothiazine toxicosis may cause corneal opacity (WHITTAKER et al., 2003). Corneal edema is a common clinical sign of corneal ulceration, keratitis, anterior uveitis, and many systemic diseases, and precludes the direct visualization of intraocular structures by ophthalmoscopy (WHITTAKER et al., 2003). Under such conditions, alternative diagnostic methods for intraocular diseases must be explored (BOROFFKA et al., 1998; BENTLEY et al., 2003; SCOTTY et al., 2004).

In the scope of investigative ophthalmology, the eyes of goats are frequently used in in vitro research, notably in pharmacodynamic studies of drugs (PAWAR \& MAJUMDAR, 2007), or for training novice surgeons in different techniques of phacoemulsification for cataract removal (DADA \& SIDHU, 2000; SUDAN et al., 2002). However, knowledge of ophthalmic parameters in this species is still sparse and must be defined (GALÁN et al., 2006; MORALES et al., 2006; BROADWATER et al., 2007).

Transcorneal ultrasonography enables the evaluation of intraocular structures in opaque eyes. Ocular biometry is a useful tool for the assessment of abnormalities such as phthisis bulbi, microphthalmia, pseudoexophthalmia, scleral ectasia, and congenital glaucoma (BRANDÃO et al., 2007; POTTER et al., 2008). They allow calculations of intraocular lens dioptric power to be employed in eyes of animals that have undergone cataract surgery to achieve emmetropia (SAMPAIO et al., 2002; McMULLEN \& GILGER, 2006; ZHOU et al., 2006; CARTER et al., 2007). Additionally, biometry values are frequently used for the construction of schematic eyes in optics (GÖRIG et al., 2006).

Knowledge of the ultrasonographic appearance and normal dimensions of the eye would serve as a basis for ultrasonographic examinations when ocular disease may have caused alterations in the dimensions and appearance (BENTLEY et al., 2003; SCOTTY et al., 2004; POTTER et al., 2008). For this reason, the aim of this research was to study the dimensions (ecobiometry) and the ultrasonographic aspect of adult goats.

\section{MATERIALSANDMETHODS}

Thirty adult Boer/Alpine cross breed goats (Capra hircus) (60 eyes) (15 intact females and 15 castrated males), with an average age of 549 days were used in this study. Prior to ultrasonographic evaluation, all subjects underwent a complete ophthalmic examination based on dazzle and pupillary reflexes, Schirmer tear test $\mathrm{t}^{\mathrm{a}}$, slit lamp biomicroscopy ${ }^{\mathrm{b}}$, intraocular pressure ${ }^{\mathrm{c}}$, binocular indirect ophthalmoscopy ${ }^{\mathrm{d}}$, and fluorescein staining $\mathrm{e}^{\mathrm{e}}$.
A- and B- mode ultrasonography ${ }^{\mathrm{f}}$ were performed in both eyes simultaneously by the same operator after administration of a topical anestheticg. Lubricating jelly ${ }^{\mathrm{h}}$ was placed on the $20 \mathrm{MHz}$ transducer tip as a stand-off pad. The transducer was placed in a longitudinal position (sagittal plane) until optimal Bscan images, according to echoes of the A-mode, were obtained. The anterior chamber depth was measured as the distance between echoes from the posterior corneal surface and the anterior lens surface. The lens thickness was the distance between echoes from the anterior and posterior lens surfaces. The vitreous chamber depth was the distance between echoes from the posterior lens surface and the retina. The axial globe length was measured from the posterior corneal surface to the retina. For all measurements, the gain was set at $80 \mathrm{~dB}$, and the velocity of sound was $1,532 \mathrm{~m} \mathrm{~s}^{-1}$ for the anterior chamber, $1,641 \mathrm{~m} \mathrm{~s}^{-1}$ for the lens, and $1,523 \mathrm{~m} \mathrm{~s}^{-1}$ for the vitreous chamber at a depth of $4.0 \mathrm{~cm}$. Gender data were compared using $T$ test $\mathrm{t}^{\mathrm{i}}$. A value of $P<0.05$ was considered to be significant.

\section{RESULTS}

In accordance with the ultrasonographic findings in other domestic species, the aqueous and vitreous humors of the goats, as well as the lens cortices and nuclei, appeared anechoic. The cornea, anterior and posterior lens capsule, sclera and iris appeared hyperechoic, and generated peaks on the A-mode (Figure 1). The cornea generated two peaks on the Amode, the first one corresponding to its epithelium, and the second to its Descemet membrane. On the Bmode, the iris was identified as being immediately adjacent to the anterior lens capsule with the thicker, more irregular ciliary body located adjacent to it. The scleroretinal rim appeared as a concave echogenic line; the three layers that comprise this anatomical site could not be differentiated ultrasonographically. The head of the optic nerve casts acoustic shadows from its margins. The ciliary artery could not be identified in any of the eyes studied.

Regarding ecobiometric measurements, for all parameters evaluated, significant differences were not observed between male and female subjects $(P>0.05)$. The descriptive statistical data of the ecobiometric values measured in adult male and female goats are summarized in table 1.

\section{DISCUSSION}

The aspheric nature of bovine eye species was also observed in the present study, in which eyes 


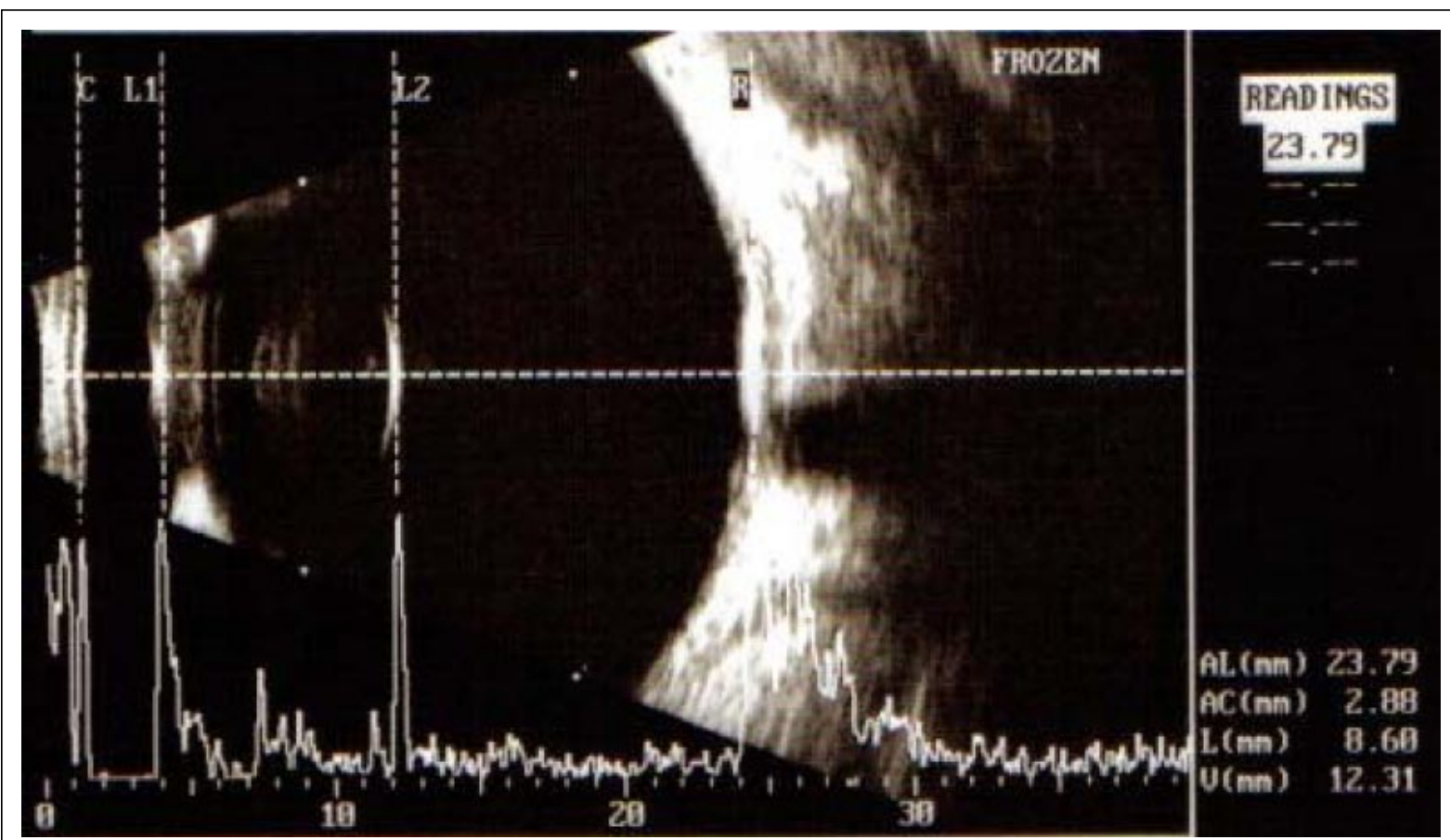

Figure 1 - A- and B- mode ultrasonogram of an adult female goat eye. C: cornea; L1: anterior capsule; L2: posterior capsule; and R: retina. Axial globe length (AL), anterior chamber $(\mathrm{AC})$, lens $(\mathrm{L})$ and vitreous chamber $(\mathrm{V})$.

of goats were evaluated (POTTER et al., 2008). In addition, the ultrasonographic appearance of goat eyes showed great similarity in comparison to other domestic species (GILGER et al., 1998; OSUOBENI \& HAMIZADA, 1999; BRANDÃO et al., 2004; McMULLEN \& GILGER, 2006; POTTER et al., 2008). Ultrasonographic studies accomplished in two distinct bovine breeds were able to identify the ciliary artery in $70 \%$ of the animals examined (POTTER et al., 2008). In the present research, however, it was not possible to visualize the ciliary artery in both male and female goats, probably because of the axial globe length of the goats eyes, which are $27 \%$ smaller $(23.41 \mathrm{~mm})$ than the average axial globe length of bovines eyes $(33.65 \mathrm{~mm})$ (POTTER et al., 2008).

Regarding to ecobiometry, studies of caprine species were not found in the literature. The ecobiometric values measured for adult goats resemble those obtained from Ile de France Sheep of 11 months of age (BRANDÃO et al., 2004). Although feasible, it was decided not to measure the axial corneal thickness since such measurement can be overestimated ultrasonographically given difficulties in positioning the calipers exactly on the corneal surfaces. In addition, some depression in the corneal axial region may occur due to transducer pressure generating biases (POTTER et al., 2008). For all parameters measured, significant differences were not observed between male and female subjects of the same age. Our findings contrast with the results of previous reports, which stated that adult women had shorter axial globe length, shallower anterior and vitreous chamber depth, and thicker lenses than adult men (WONG et al, 2001; WARRIER et al., 2008). Other paper also reported that axial globe length of adult male dogs was found to be significant longer than that of adult female dogs (SCHIFFER et al., 1982). Considering that all adult males used in the research were castrated, differences related to ecobiometric readings could be found if intact males and a larger sample of goats were studied. Although not significant, minimum and maximum values of anterior chamber depth in males $(1.80 \mathrm{~mm})$ and females $(1.98 \mathrm{~mm})$ goats varied. Such variances may be attributed to ocular irritation after jelly instillation and tip of ultrasound probe, which may reduce intraocular pressure values, consequently reducing anterior chamber depth due to antidromic stimuli (KROHNE et al, 1988).

Although discrepancies relative to intra- and interobserver repeatability are acceptable for measuring intraocular structures by means of B-mode ultrasonography in dogs (BOROFFKA et al., 2006), it was decided that all examinations would be done by the same person. OSUOBENI \& HAMIZADA (1999) observed that there can be differences in the readings 
Table 1 - Descriptive statistics of ecobiometric values (in millimeters) in male and female adult goats.

\begin{tabular}{|c|c|c|c|c|}
\hline & $\begin{array}{c}\text { Axial globe } \\
\text { length } \\
\mathrm{P}=0.91 *\end{array}$ & $\begin{array}{c}\text { Anterior } \\
\text { chamber depth } \\
\mathrm{P}=0.49^{*}\end{array}$ & $\begin{array}{c}\text { Lens } \\
\text { thickness } \\
\mathrm{P}=0.73^{*}\end{array}$ & $\begin{array}{c}\text { Vitreous } \\
\text { chamber depth } \\
\mathrm{P}=0.84^{*}\end{array}$ \\
\hline \multicolumn{5}{|l|}{ Male } \\
\hline Mean \pm SD & $23.43 \pm 0.92$ & $3.46 \pm 0.55$ & $8.60 \pm 0.34$ & $11.34 \pm 0.61$ \\
\hline Confidence interval & 0.51 & 0.29 & 0.18 & 0.34 \\
\hline Maximum & 24.65 & 4.29 & 9.25 & 12.16 \\
\hline Minimum & 21.94 & 2.49 & 8.18 & 9.90 \\
\hline \multicolumn{5}{|l|}{ Female } \\
\hline Mean \pm SD & $23.39 \pm 0.86$ & $3.33 \pm 0.46$ & $8.65 \pm 0.39$ & $11.39 \pm 0.66$ \\
\hline Confidence interval & 0.48 & 0.24 & 0.21 & 0.36 \\
\hline Maximum & 24.78 & 4.21 & 9.35 & 12.39 \\
\hline Minimum & 21.78 & 2.73 & 7.68 & 10.13 \\
\hline
\end{tabular}

* $P$ value among genders assessed by $T$ test.

ocular structures of camels obtained from A- and Bmode ultrasonography, with the A-mode being the most reliable method. Likewise, it was verified that sedation decreases the likelihood of errors during measurements with A-mode ultrasonography (EKESTEN, 1994). Notwithstanding, in this study good ultrasonograms were obtained with animals under physical restraint and topical anesthesia. In another study on cadaveric ovine eyes, it was assumed that ocular distances vary in accordance with the method employed: A- and Bmode ultrasonography, or caliper rule (BRANDÃO et al., 2004). For these reasons, in the present research, it was decided to calculate all measurements using Amode ultrasonography.

The high-resolution $20 \mathrm{MHz}$ transducer used in our study offers a power of penetration ranging from 2 to $6 \mathrm{~cm}$, which is necessary to visualize the entire globe, without the formation of reverberation artifacts in the anterior chamber (BENTLEY et al., 2003). Compared with conventional $10 \mathrm{MHz}$ probes that have resolutions of 300 to $400 \mu \mathrm{m}$, high-frequency probes $(20 \mathrm{MHz})$ enable imaging at resolutions comparable to low-power microscopic views $(20 \mu \mathrm{m})$ (FOSTER et al., 2000). However, in the equipment used in the present study, the minimum power of penetration is limited to $20 \mathrm{~mm}$, not reaching lower tissue penetrations of 5 to $10 \mathrm{~mm}$, which are necessary to visualize structures such as the ciliary cleft (BENTLEY et al., 2003).

The ultrasound machine used during this research was calibrated to acoustic wave propagation velocities for ocular tissue of humans at $1,532 \mathrm{~m} \mathrm{~s}^{-1}$ for the anterior chamber, $1,641 \mathrm{~m} \mathrm{~s}^{-1}$ for the lens, and $1,523 \mathrm{~m}$ $\mathrm{s}^{-1}$ for the vitreous chamber (GÖRIG et al., 2006). The speed of sound waves in ocular tissues is not constant, particularly in the lens where it slows gradually from the center of the structure to the periphery (van der STEEN et al., 1994). Tissue velocities through the aqueous and vitreous mediums are similar to that in water at a similar temperature, while velocities are higher through the lens, where the value is $1650 \mathrm{~m} \mathrm{~s}^{-1}$ (GÖRIG et al., 2006). Recent data indicate that conversion factors for the speed of sound waves through lens tissue are needed to accurately perform comparative quantitative A-mode ultrasound studies (GÖRIG et al., 2006). For example, an underestimation of approximately $4 \%$ results when calculations of the lens thickness in dogs are made on the basis of sound wave speeds in human tissues. In contrast, the error in the estimation of vitreous body depth is approximately $0.2 \%$, and is thus negligible (GÖRIG et al., 2006). Considering that the values of the axial lens thickness obtained herein for adult goats $(8.63 \pm 0.36 \mathrm{~mm})$ are considerably larger than that of adult humans $(4.75 \pm 0.47 \mathrm{~mm})$ (WONG et al, 2001), acoustic wave propagation velocities in the ocular tissues of goats may have lead to some discrepancies during ultrasonographic measurements in this study.

The results of this research showed that dimensions of anterior chamber, lens, vitreous chamber and axial globe length of adult goats did not differ between the genders. Ultrasonographically, intraocular chambers and structures resemble those observed for other animal species. The knowledge of normal ocular dimensions facilitates the use of ultrasonography in the evaluation of ocular disease in adult goats.

\section{ETHICS COMMITTEE ON ANIMAL EXPERIMENTATION}

This study was approved by the Ethics Committee on Animal Experimentation (Protocol number 016240/09), and followed the ethical norms of the Association for Research in Vision and Ophthalmology ARVO (National Institutes of Health, Publications no. 85-23, revised 1985).

\section{SOURCES OFACQUISITION}

a - Teste de Schirmer ${ }^{\circledR}$, Ophthalmos - São Paulo - SP
b - Portable SL $14^{\circledR}$, Kowa - Japan

Ciência Rural, v.40, n.3, mar, 2010. 
c - Tonopen $\mathrm{XL}^{\circledR}$, Mentor O\&O - Norwell

d - Oftalmoscópio binocular indireto $\mathrm{OHC}^{\circledR}$, Eye Tec - São Carlos - SP

e - Fluoresceína Strips ${ }^{\circledR}$, Ophthalmos - São Paulo - SP

f - Ultra $\operatorname{Scan}^{\circledR}$, Alcon, Irvine, CA, USA.

g - Anestalcon ${ }^{\circledR}$, Alcon, São Paulo, SP, Brasil.

i - Carbogel - ULT, Carbogel indústria e comércio LTDA, São Paulo, SP, Brasil.

i - SigmaStat $3.0^{\circledR}$, Systat Software inc - San Jose, CA, USA.

\section{REFERENCES}

BENTLEY, E. et al. Use of high-resolution ultrasound as a diagnostic tool in veterinary ophthalmology. Journal of the American Veterinary Medical Association, v.223, n.11, p.1617-1622, 2003. Available from: http:// avmajournals.avma.org/toc/javma/223/11. Accessed: aug. 04, 2009. doi: $10.2460 /$ javma.2003.223.1617.

BOROFFKA, S.A.E.B. et al. Ultrasonographic diagnosis of persistent hyperplastic tunica vasculosa lentis/persistent hyperplastic primary vitreous in two dogs. v.39, n.5, p.440444, 1998. Available from: http://www3.interscience.wiley.com/ journal/118999661/abstract. Accessed: aug. 04, 2009. doi: 10.1046/j.1463-5224.2001.00177.x.

BOROFFKA, S.A.E.B. et al. Intraobserver and interobserver repeatability of ocular biometric measurements obtained by means of B-mode ultrasonography in dogs. American Journal of Veterinary Research, v.67, n.10, 1743-1749, 2006. Available from: http://avmajournals.avma.org/doi/abs/10.2460/ ajvr.67.10.1743. Accessed: aug. 04, 2009. doi: 10.2460/ ajvr.67.10.1743.

BRANDÃO, C.V.S. et al. Comparação entre ultra-sonografia modo-A, modo-B e medidas diretas em olhos de ovinos. Brazilian Journal of Veterinary Research and Animal Science, 41S:68-69, 2004.

BRANDÃO, C.V.S. et al. Tonometry, pachymetry and globe axial lenght in glaucomatous dogs submitted to intravitreal uveal ablation. Brazilian Journal of Veterinary and Animal Science, Belo Horizonte, v.59, n.4, p.914-919, 2007. Available from: 10.1590/S0102-09352007000400016. http:// www.scielo.br/pdf/abmvz/v59n4/16.pdf. Accessed: aug. 04, 2009. doi: 10.1590/S0102-09352007000400016.

BROADWATER J.J. et al. Ophthalmic examination findings in adult pygmy goats (Capra hicus). Veterinary Ophthalmology, v.10, n.5, p.269-273, 2007. Available from: http:// www3.interscience.wiley.com/journal/ $118507758 /$ abstract?CRETRY=1\&SRETRY=0. Accessed: aug. 04, 2009. doi: $10.1111 / \mathrm{j} .1463-5224.2007 .00548 . x$.

CARTER, R.T. et al. Bilateral phacoemulsification and intraocular lens implantation in a great horned owl. Journal of the American Veterinary and Medical Association, v.230, n.4, p.559-561, 2007. Available from: http:// avmajournals.avma.org/doi/abs/10.2460/javma.230.4.559. Accessed: aug. 04, 2009. doi: 10.2460/javma.230.4.559.

DADA, V.K.; SINDHU, N. Cataract in enucleated goat eyes: training model for phacoemulsification. Journal of Cataract and Refractive Surgery, v.26, n.8, p.1114-1116, 2000. Accessed: aug. 04, 2009. Available from: http://
www.jcrsjournal.org/article/S0886-3350(00)00448-X/abstract. doi: S0886-3350(00)00448-X.

EKESTEN, B. Biological variability and measurement error variability in ocular biometry in Samoyed dogs. Acta Veterinaria Scandinavica, v.35, n.4, 427-433, 1994.

FOSTER F.S. et al. Advances in ultrasound biomicroscopy. Ultrasound in Medicine and Biology, v.26, n.1, p.1-27, 2000. Available from: http://www.umbjournal.org/article/S03015629(99)00096-4/abstract. Accessed: aug. 04, 2009. doi: 10.1016/S0301-5629(99)00096-4.

GALÁN, A. et al. Ophthalmoscopic characteristics in sheep and goats: comparative study. Journal of Veterinary Medicine A, v.53, n.4, p.205-208, $2006 . \quad$ Available from: http://www.ingentaconnect.com/content/bsc/jva/2006. Accessed: aug. 04, 2009. doi: 10.1111/j.14390442.2006.00811.x.

GILGER, B.C. et al. Keratometry, ultrasonic biometry, and prediction of intraocular lens power in the feline eye. American Journal of Veterinary Research, v.59, n.2, p.131-134, 1998.

GÖRIG, C. et al. Evaluation of acoustic wave propagation velocities in the ocular lens and vitreous tissues of pigs, dogs, and rabbits. American Journal of Veterinary Research, v.67, n.2, p.288-295, 2006. Available from: http:// avmajournals.10.2460/ajvr.67.2.288. Accessed: aug. 04, 2009. doi: 10.2460 /ajvr.67.2.288.

HAMIDZADA, W.A.; OSUOBENI, E.P. Agreement between A-mode and B-mode ultrasonography in the measurement of ocular distances. Veterinary Radiology and Ultrasound, v.40, n.5, p.502-507, 1999. Available from: http:// www3.interscience.wiley.com/journal/119097596/abstract. Accessed: aug. 04, 2009. doi: 10.1111/j.17408261.1999.tb00382.x.

KROHNE, G.S. et al.; Inhibition of pilocarpine-induced aqueous humor flare, hypotony, and miosis by topical administration of anti-inflamatory and anestesic drugs to dogs. American Journal of Veterinary Research. v.59, n.4, p.482-488, 1998.

McMULLEN, R.J.Jr.; GILGER, B.C. Keratometry, biometry and prediction of intraocular lens power in the equine eye. Veterinary Ophthalmology, v.9, n.5, p.9:357-360, 2006. Available from: http://www3.interscience.wiley.com/journal/ 118599216/abstract. Accessed: aug. 04, 2009. doi: 10.1111/ j.1463-5224.2006.00493.x.

MORALES, I. et al. Ocular lesions associated with Trypanosoma evansi in experimentally infected goats. Veterinary Parasitology, v.141, n.3-4, p.325-329, 2006. Available from: http:// www.sciencedirect.com/science. Accessed: aug. 04, 2009. doi:10.1016/j.vetpar.2006.06.007

OSUOBENI, E.P.; HAMIDZADA, W.A. Ultrasonographic determination of the dimensions of ocular components in enucleated eyes of the one-humped camel (Camelus dromedarius). Research in Veterinary Science, v.67, n.2, p.125-129, 1999. Available from: http://www.sciencedirect.com/ science. Accessed: aug. 04, 2009. doi: 10.1053/rvsc.1998.0288.

PAWAR, P.K.; MAJUMDAR, D.K. In vitro permeation characteristics of moxifloxacin from oil drops through 
excised goat, sheep, buffalo and rabbit corneas. Phramazie, v.62, n.11, p.853-857, 2007. Available from: http:// www.atypon-1ink.com/G VR/doi/abs/10.1691/ ph.2007.11.7055. Accessed: aug. 04, 2009. doi: pdf/10.1691/ ph.2007.11.7055.

POTTER, T.J.; et al. Ultrasonographic anatomy of the bovine eye. Veterinary Radiology and Ultrasound, v.49, n.2, p.172175, 2008. Available from: . Accessed: aug. 04, 2009. doi: $10.1111 /$ j.1740-8261.2008.00345.x.

SAMPAIO, G. R. et al. Sexo, peso e conformação anatômica do olho sobre cálculo de poder dióptrico de lentes intra-oculares no cão. Ciência Rural, v.32, n.2, p.263-268, 2002. Available from: http://www.scielo.br/pdf/cr/v32n2/a13v32n2.pdf . Accessed: aug. 04, 2009. doi: 10.1590/S010384782002000200013 .

SCHIFFER, S.P. et al. Biometric study of the canine eye, using A-mode ultrasonography. American Journal of Veterinary Research, v.43, n.5, p.826-830, 1982.

SCOTTY, N.C. et al. Diagnostic ultrasonography of equine lens and posterior segment abnormalities. Veterinary Ophthalmology, v.7, n.2, p.127-139, 2004. Available from: http://www3.interscience.wiley.com/journal/118811868/ abstract. Accessed: aug. 04, 2009. doi: 10.1111/j.14635224.2004.04009.x

SUDAN, R. et al. Formalin-induced cataract in goat eyes as a surgical training model for phacoemulsification. Journal of Cataract and Refractive Surgery, v.28, n.11, p.1904-1906,
2002. Available from: http://www.jcrsjournal.org/article/S08863350(02)01327-5/abstract. Accessed: aug. 04, 2009. doi: 10.1016/S0886-3350(00)00448-X

VAN DER STEEN, A.F.W. et al. Ultrasonic spectroscopy of the porcine eye lens. Ultrasound in Medicine and Biology, v.20, n.9, p.967-974, 1994. Available from: http:// www.sciencedirect.com/scienceinfo. Accessed: aug. 04, 2009. doi:10.1016/0301-5629(94)90055-8

ZHOU, X. et al. Normal development of refractive state and ocular dimensions in guinea pigs. Vision Research, v.46, n.18, p.2815-2823, 2006. Available from: http:// www.sciencedirect.com/science. Accessed: aug. 04, 2009. doi:10.1016/j.visres.2006.01.027.

WARRIER, S. et al. Ocular biometry and determinations of refractive error in rural Myanmar: the Meiktila Eye Study. British Journal of Ophthalmology, v.92, n.12, p.15911594, 2008. Available from: http://bjo.bmj.com/cgi/content/ abstract/92/12/1595. Accessed: aug. 04, 2009. doi: 10.1136/ bjo. 2008.144477 .

WHITTAKER, C.J.G. et al. Oftalmologia em animais de produção. In: GELATT, K.N. Oftalmologia veterinária. Manole: Barueri, 2003, p.377-412.

WONG, T.Y; et al.Variations in ocular biometry in an adult Chinese population in Singapore: the Tanjong Pagar Survey. Investigative Ophthalmology and Visual Science, v.42, n.1, p.73-80, 2001. Available from: http://www.iovs.org/cgi/ reprint/42/1/73. Accessed: aug. 04, 2009. 